\title{
DIVERSIFIKASI DAN KARAKTERISASI CITARASA BAKSO IKAN TENGGIRI (Scomberomus commerson) DENGAN PENAMBAHAN ASAP CAIR TEMPURUNG KELAPA
}

\author{
DIVERSIFICATION AND CHARACTERIZATION FLAVOR OF “TENGGIRI FISH \\ (Scomberomus commerson) MEATBALL” ON ADDING \\ THE LIQUID SMOKE OF COCONUT SHELL
}

\author{
Nur Her Riyadi ${ }^{1)}$ dan Windi Atmaka ${ }^{1)}$ \\ 1) Staf Pengajar Jurusan Ilmu dan Teknologi Pangan, FP, Universitas Sebelas Maret, Surakarta
}

\begin{abstract}
Consumers have lean toward food product with smoke flavor increased. Recently, the emerge of unusual food product with the smoke flavor such as roasted rice, roasted soybean curd, and roasted coconut are intensed. But direct fogging creates carsinogenic matterial. Usage of liquid smoke is one of the alternative way to fix up fogging procces in order to get food product with safe smoke flavor for health. Tenggiri fish has a high level of productivity and has much nutrient. Fish meatball is one of fished product diversification. Meatball itself is a popular food product. But as long as meatball flavor still low, it has potential to be improved. For example it can be modified by adding smoke flavor to Tenggiri fish meatball.

The objectives of this research were to know the exact method and concentrate level of liquid smoke adding to Tenggiri fish meatball that cause the highest level of acceptability, to know sensory characteristics (color, smoke flavor, elasticity, and overall) and also to know physical (texture) characteristic and chemical characteristics (water content, fat, protein, and fenol) from Tenggiri fish meatball with highest level of acceptability. Research design that be used was randomized completely factorial design, consist of 2 factors: Variation of liquid smoke adding methode (mixing, dyeing, and spraying); and variation of liquid smoke concentration $(3 \%, 5 \%, 7 \%)$. It was analized by ANOVA at $\alpha=5 \%$, then to be analyzed with DMRT if there was significant differences.

The research showed that variation of methode and concentration of liquid smoke adding to the Tenggiri fish meatball gave no significant impact on color sensory, elasticity and overall, but influenced smoke flavor. Tenggiri fish meatball which was sprayed by 3\% of liquid smoke got the highest level of acceptability. Chemical characteristic of tenggiri fish meatball which was sprayed by 3\% of liquid smoke has been proved appropriate with the standart of SNI for fish meatball criteria: 75,06 of water content; 10,16\% of protein; $0,86 \%$ of fat. It was also contain $0,07061 \%$ of nature fenol which was still under limit/tolerance of fenol content $(0,02-0,1 \%)$ for food so that it was safe to be consumed and acceptabel for its physical, chemical and sensory characteristic.
\end{abstract}

Keywords : flavor, liquid smoke, meatball

\begin{abstract}
ABSTRAK
Kecenderungan konsumen terhadap produk pangan bercitarasa asap semakin meningkat. Bahkan akhir-akhir ini muncul produk pangan bercitarasa asap yang dahulu tidak lazim diperdagangkan seperti nasi bakar, tahu bakar dan kelapa bakar. Namun, pengasapan cara langsung memungkinkan terbentuknya senyawa karsinogenik. Penggunaan asap cair merupakan salah satu alternatif untuk memperbaiki proses tersebut sehingga dihasilkan produk pangan bercitarasa asap yang aman bagi kesehatan. Ikan tenggiri mempunyai tingkat produksi dan kandungan gizi yang cukup tinggi. Bakso ikan merupakan salah satu bentuk diversifikasi produk perikanan. Bakso merupakan salah satu produk yang paling digemari. Namun, sejauh ini citarasa bakso masih standar sehingga berpotensi untuk dikembangkan. Salah satunya adalah dengan cara menambahkan citarasa asap pada produk bakso ikan tenggiri.

Tujuan penelitian ini adalah untuk mengetahui metode dan konsentrasi pemberian asap cair pada bakso ikan tenggiri yang memiliki tingkat kesukaan paling tinggi, mengetahui karakter sensoris (warna, aroma asap, rasa asap, kekenyalan dan keseluruhan) serta untuk mengetahui karakter fisik (tekstur) dan karakter kimia (kadar air, lemak, protein dan fenol) terhadap bakso ikan tenggiri citarasa asap yang paling disukai. Rancangan yang digunakan adalah Rancangan Acak Lengkap (RAL) pola faktorial yang terdiri dari 2 faktor yaitu variasi metode penambahan asap cair (pencampuran, pencelupan dan penyemprotan) serta variasi konsentrasi asap cair (3\%, 5\% dan 7\%). Analisis data secara statistik dengan ANOVA pada $\alpha=5 \%$ serta dilanjutkan dengan uji DMRT apabila ada beda nyata.

Hasil penelitian menunjukkan bahwa variasi metode serta konsentrasi pemberian asap cair pada bakso ikan tenggiri tidak memberikan pengaruh beda nyata terhadap sifat sensori warna, kekenyalan serta keseluruhan tetapi memberikan pengaruh bervariasi terhadap sifat sensori aroma asap dan rasa asap. Bakso ikan tenggiri dengan metode penyemprotan asap cair 3\% merupakan metode serta konsentrasi pemberian asap cair yang memiliki tingkat kesukaan paling tinggi. Karakteristik kimia bakso ikan tenggiri dengan penyemprotan asap cair 3\% telah
\end{abstract}


sesuai dengan persyaratan SNI bakso ikan yaitu: kadar air 75,06\%, kadar protein 10,16\% dan kadar lemak $0,86 \%$. Mengandung fenol alami sebesar $0,07061 \%$ dan masih jauh di bawah batas maksimal kadar fenol yang diperbolehkan dalam bahan makanan $(0,02-0,1 \%)$ sehingga aman untuk dikonsumsi serta dapat diterima konsumen dari karakter sensoris, fisik dan kimia.

Kata kunci : asap cair, bakso ikan, cita rasa.

\section{PENDAHULUAN}

Sekarang ini kecenderungan konsumen terhadap produk pangan bercita rasa asap semakin meningkat. Hal ini terlihat dari banyaknya pilihan produk pangan bercita rasa asap seperti ayam bakar, lele bakar, sate, steak dan lain sebagainya. Bahkan akhirakhir ini muncul produk pangan bercita rasa asap yang dahulu tidak lazim diperdagangkan seperti nasi bakar, tahu bakar dan kelapa bakar. Namun, Gorbatov et al., (1971) dan Maga (1987) mengungkapkan bahwa pengasapan dengan cara langsung (dipanggang di atas api kayu) tersebut mempunyai beberapa kekurangan, yaitu flavor dan konsentrasi konstituen asap yang diinginkan sulit diatur, produk yang dihasilkan tidak seragam karena waktu dan suhu yang optimal tidak dapat dipertahankan sama serta kemungkinan terbentuk senyawa PAH (Polisiklik Aromatik Hidrokarbon)/benzo(a)piren yang bersifat karsinogenik. Oleh sebab itu, untuk memperbaiki proses tersebut perlu dikembangkan cara pengolahan produk pangan bercita rasa asap yang aman bagi kesehatan.

Asap cair merupakan kondensat dari asap kayu yang telah mengalami penyimpanan dan penyaringan untuk memisahkan tar dan bahan-bahan tertentu (Pszczola,1995). Untuk mendapatkan sifat fungsional asap cair yang diinginkan seperti sebagai antimikrobia, antioksidan, dan dapat memberikan flavor khas asap dapat dilakukan dengan cara fraksinasi karena senyawasenyawa yang terdapat dalam asap cair mempunyai titik didih yang berbeda-beda. Salah satu fraksinasi yang dapat dilakukan adalah dengan redistilasi asap cair. Suwedo, dkk (1998) juga menyatakan bahwa proses redistilasi asap cair juga dapat menghilangkan senyawa yang tidak diinginkan yaitu senyawa tar dan Polisiklis Aromatik Hidrokarbon (PAH), yang tidak aman serta mempunyai dampak yang membahayakan bagi kesehatan. Oleh Sebab itu, penggunaan asap cair ini cukup aman karena senyawa-senyawa yang mempunyai dampak membahayakan bagi kesehatan telah dihilangkan melalui proses redistilasi.

Produksi ikan tenggiri di perairan Jawa Tengah cukup tinggi. Produksi ikan tenggiri pada tahun 2005 mencapai 10.000 ton (Anonim, 2006). Ikan tenggiri memiliki kandungan gizi yang tinggi serta mutu proteinnya setingkat dengan mutu protein daging. Ikan tenggiri memiliki warna daging yang putih serta memiliki kandungan aktin dan myosin cukup tinggi (Anonim, 2004). Mengingat potensi perikanan di Indonesia sangat besar, peluang pengembangan usaha perikanan yang cukup besar serta potensi budidaya tambak yang cukup berarti maka perlu dikembangkan pemanfaatannya. Wibowo (1995) menyatakan bahwa bakso merupakan salah satu bentuk diversifikasi pemanfaatan produk hasil perikanan.

Bakso merupakan salah satu produk yang paling banyak digemari konsumen. Mulai dari anak-anak hingga dewasa bahkan orang tua. Rasanya lezat, bergizi tinggi, dapat disantap dengan dan dalam kondisi apapun serta sangat mudah diterima oleh siapa saja (Wibowo, 1995). Namun, sejauh ini citarasa bakso masih standar sehingga berpotensi untuk dikembangkan. Salah satunya adalah dengan cara menambahkan citarasa asap pada produk bakso ikan tenggiri. Diharapkan dengan adanya penelitian ini, aplikasi asap cair untuk memberi citarasa asap pada produk-produk makanan dapat lebih berkembang dan dapat digunakan secara optimal.

\section{METODE PENELITIAN}

\section{Bahan}

Bahan yang digunakan untuk pembuatan bakso ikan tenggiri adalah daging ikan tenggiri yang berasal dari pasar lokal di 
Surakarta, garam dapur merk Refina, bawang putih, es batu, tepung tapioka, STPP dan redistilat asap cair yang berasal dari Fakultas Teknologi Pangan UGM. Bahan yang digunakan untuk uji kadar protein adalah katalis $\mathrm{N}$ campuran $\mathrm{K}_{2} \mathrm{SO}_{4}$ : $\mathrm{CuSO}_{4}, \mathrm{H}_{2} \mathrm{SO}_{4}$, $\mathrm{NaOH} 0,1 \mathrm{~N}$, etanol, indikator $\mathrm{MR}, \mathrm{HCl} 0,1$ $\mathrm{N}$, dan sampel bakso. Bahan untuk uji kadar lemak adalah pelarut petroleum eter, dan sampel bakso. Bahan untuk uji kadar air dan tekstur adalah sampel bakso. Bahan untuk uji kadar fenol adalah redistilat asap cair, sampel bakso, $\mathrm{Na}_{2} \mathrm{CO}_{3}$ alkali $2 \%$, folin ciopcalteau, aquades dan fenol murni.

\section{Alat}

Alat yang digunakan untuk pengolahan bakso ikan tenggiri adalah pisau, panci, telenan, blender, mixer, dan kompor. Alat yang digunakan untuk uji kadar air (botol timbang, desikator, oven, penjepit dan neraca analitik), uji kadar lemak (alat ekstraksi soxhlet, desikator, kertas saring bebas lemak, dan neraca analitik), uji protein (labu kjeldahl, desikator, gelas ukur, pemanas listrik, buret, Erlenmeyer, dan neraca analitik), alat untuk uji sifat mekanik tekstur (Llyoid Instruments) serta alat untuk uji kadar fenol (vortex dan spektrofotometer).

\section{Metode}

Penelitian dimulai dengan penghilangan bagian kulit, tulang/duri serta kepala ikan tenggiri sehingga diperoleh daging ikan tenggiri dalam bentuk filet. Maksud pemisahan ini adalah untuk memudahkan proses penghancuran daging. Filet ikan tenggiri seberat 300 gram selanjutnya digiling dengan terlebih dahulu daging ikan dipotong-potong kecil setebal 0,5-0,7 cm dengan ditambahkan es batu (ukuran diperkecil/dipotong) sebanyak 75 gram ( $25 \%$ berat daging).

Selanjutnya garam 6 gram $(2 \%$ berat daging) dan bumbu (merica 1 gram, bawang putih 5 gram) dicampur dan dihaluskan supaya homogen kemudian dimasukkan ke dalam adonan (ikan yang telah digiling) untuk dimixer kembali. Kemudian setelah tercampur merata, ke dalam daging lumat tersebut ditambahkan sedikit demi sedikit tepung tapioka 45 gram (15\% berat daging) serta ditambahkan Sodium Tripoliposphat
(STPP) 0,5\% berat daging atau 1,5 gram (keduanya terlebih dahulu dicampurkan supaya homogen) dan dilumatkan hingga diperoleh adonan yang homogen. Adonan yang telah homogen dicetak menjadi bolabola bakso yang siap direbus. Bola-bola bakso direbus dalam air $70-80^{\circ} \mathrm{C}$ selama 10 15 menit hingga matang (Wibowo, 1995).

Selanjutnya dilakukan diversivikasi citarasa dengan penambahan asap cair yang bertujuan untuk menentukan desain proses yang tepat untuk memberikan citarasa asap dengan asap cair pada pembuatan bakso ikan tenggiri. Penelitian yang dilakukan meliputi penentuan metode serta konsentrasi penambahan asap cair pada bakso ikan tenggiri. Parameter keberhasilan metode serta konsentrasi penambahan asap cair adalah citarasa asap muncul sesuai keinginan panelis (memiliki tingkat kesukaan paling tinggi). Hal ini dilakukan untuk mengetahui tingkat penerimaan konsumen terhadap bakso ikan tenggiri bercita rasa asap.

Penentuan penambahan citarasa asap dilakukan dengan tiga metode serta tiga konsentrasi yaitu:

a. Pencampuran

Penambahan asap cair pada metode ini yaitu dilakukan dengan cara mencampurkan larutan asap cair konsentrasi 3\%, 5\% dan 7\% pada adonan bakso ikan tenggiri. Rasio penambahan asap cair pada adonan sebesar 10:1 (b/v).

b. Pencelupan

Penambahan asap cair pada metode ini yaitu dilakukan dengan cara mencelupkan bakso ikan tenggiri sesaat setelah perebusan dalam larutan asap cair konsentrasi $3 \%, 5 \%$ dan $7 \%$ selama 1 menit.

c. Penyemprotan

Penambahan asap cair pada metode ini yaitu dilakukan dengan cara menyemprotkan larutan asap cair konsentrasi $3 \%, 5 \%$ dan $7 \%$ pada bakso ikan tenggiri sesaat setelah perebusan. Rasio penyemprotan asap cair pada adonan sebesar 2:1 (b/v).

Selanjutnya dilakukan karakterisasi bakso. Karakterisasi bakso ikan tenggiri meliputi karakteristik kimia (kadar air, protein, lemak dan fenol) serta karakteristik 
fisik (tekstur) pada bakso ikan tenggiri dengan penambahan asap cair pada metode serta konsentrasi yang memiliki tingkat kesukaan paling tinggi.

a. Karakteristik Sensoris

Pengujian karakteristik sensoris dilakukan dengan uji organoleptik. Uji organoleptik yang dilakukan meliputi uji pembedaan dan uji kesukaan dengan metode skoring. Uji organoleptik dilakukan dengan menggunakan 20 panelis terpilih. Atribut mutu yang ditentukan dalam uji pembedaan adalah aroma asap, rasa asap dan kekenyalan sedangkan uji atribut warna serta keseluruhan dengan uji kesukaan (Kartika, dkk 1988).

b. Karakteristik Fisik

Tekstur bakso ikan tenggiri dengan Llyoid Instruments.

c. Karakteristik Kimia

Analisis kimia dilakukan untuk sampel bakso ikan tenggiri yang paling disukai panelis. Untuk analisa kimia dilakukan pengukuran:

Kadar air dengan metode thermogravimetri(Sudarmadji, dkk 1997); Kadar protein dengan metode Kjeldahl (Sudarmadji, dkk 1997); Kadar lemak dengan metode soxhlet (Sudarmadji, dkk 1997); Kadar Fenol (Senter et al., 1989) meliputi:a. Kadar fenol bakso ikan tenggiri kontrol b.Kadar fenol bakso ikan tenggiri dengan tingkat kesukaan paling tinggi c. Kadar fenol asap cair pada konsentrasi bakso ikan tenggiri dengan tingkat kesukaan paling tinggi.

\section{HASIL DAN PEMBAHASAN}

\section{Karakteristik Sensoris Bakso Ikan Tenggiri dengan Penambahan Asap Cair}

Keistimewaan komoditas pangan dari sudut pandang mutunya ialah mempunyai nilai mutu subyektif di samping mutu objektif. Jika mutu obyektif dapat diukur dengan instrument fisik maka sifat subyektif hanya dapat diukur dengan instrument manusia. Sifat subyektif lebih umum disebut dengan sifat indrawi atau organoleptik karena penilaiannya dengan menggunakan organ manusia seperti penglihatan dengan mata, penciuman dengan hidung, pencicipan dengan rongga mulut, perabaan dengan ujung jari dan pendengaran dengan telinga. Meskipun dengan uji fisik dan kimia serta uji gizi dapat menunjukkan suatu produk pangan bermutu tinggi, namun tidak akan ada artinya jika produk tersebut tidak dapat dikonsumsi karena tidak enak atau sifat organoleptiknya tidak membangkitkan selera atau tidak dapat diterima konsumen (Soekarto, 1990).

Oleh karena itu, untuk mengetahui metode serta konsentrasi penambahan asap cair yang dapat menghasilkan bakso ikan tenggiri yang paling disukai panelis maka dilakukan uji organoleptiknya terlebih dahulu. Selanjutnya baru dilakukan uji fisik (tekstur) serta uji kimia (air, protein, lemak dan fenol) terhadap bakso ikan tenggiri dengan metode dan konsentrasi penambahan asap cair yang memiliki tingkat kesukaan paling tinggi.

\section{Warna}

Menurut Kartika, dkk (1988) warna merupakan suatu sifat bahan yang berasal dari penyebaran spektrum sinar, begitu juga dengan kilap dari bahan yang dipengaruhi oleh sinar pantul. Warna bukan merupakan suatu zat, melainkan sensasi sensoris karena adanya rangsangan dari seberkas energi radiasi yang jatuh ke indra penglihatan.

Warna adalah faktor paling menentukan menarik tidaknya suatu produk makanan (Winarno, 1991). Menurut Fennema (1985) warna adalah atribut kualitas yang paling penting. Bersama-sama dengan tekstur dan rasa, warna berperan dalam penentuan tingkat penerimaan suatu makanan. Meskipun suatu produk bernilai gizi tinggi, rasa enak dan tekstur baik namun jika warna tidak menarik maka akan menyebabkan produk tersebut kurang diminati. Kartika, dkk (1988) juga menambahkan bahwa warna merupakan salah satu profil visual yang menjadi kesan pertama konsumen dalam menilai bahan makanan. Hasil pengujian organoleptik terhadap warna bakso ikan tenggiri dengan penambahan asap cair dapat dilihat pada Tabel 1. 
Tabel 1. Hasil Uji Organoleptik terhadap Warna Bakso Ikan Tenggiri dengan Penambahan Asap Cair

\begin{tabular}{llll}
\hline \hline \multirow{2}{*}{ Perlakuan } & \multicolumn{3}{c}{ Skor Kesukaan } \\
\cline { 2 - 4 } & Asap & Asap & Asap \\
& Cair & Cair & Cair \\
& $3 \%$ & $5 \%$ & $7 \%$ \\
\hline Pencampuran & $2,25^{\mathrm{a}}$ & $2,35^{\mathrm{a}}$ & $2,30^{\mathrm{a}}$ \\
Pencelupan & $2,25^{\mathrm{a}}$ & $2,20^{\mathrm{a}}$ & $2,50^{\mathrm{a}}$ \\
Penyemprotan & $2,35^{\mathrm{a}}$ & $2,35^{\mathrm{a}}$ & $2,25^{\mathrm{a}}$ \\
\hline \hline
\end{tabular}

Ket: Angka dengan notasi yang sama berarti tidak beda nyata pada tingkat kepercayaan $95 \%$.

Skala Nilai: 1) sangat suka, 2) suka, 3) agak suka, 4) tidak suka, 5) sangat tidak suka

Tabel 1 menunjukkan bahwa bakso ikan tenggiri antar perlakuan dengan variasi metode dan konsentrasi penambahan asap cair menghasilkan warna yang tidak berbeda nyata. Secara umum nilai yang diberikan oleh panelis terhadap warna bakso ikan tenggiri dengan penambahan asap cair berkisar pada rentang nilai 2 (suka). Hal ini berarti panelis cenderung menyukai warna bakso ikan tenggiri dengan penambahan asap cair. Bakso ikan tenggiri yang dihasilkan cenderung berwarna putih.

Bakso ikan pada umumnya cenderung berwarna putih. Supaya dihasilkan warna bakso yang putih maka salah satu cara yang dilakukan adalah dengan menggunakan ikan berdaging putih. Tenggiri merupakan salah satu ikan air laut yang memiliki warna daging putih sehingga bakso yang dihasilkan cenderung berwarna putih.

\section{Aroma Asap}

Aroma merupakan sensasi sensoris yang dialami oleh indra pembau. Menurut De mann (1989), dalam industri pangan pengujian aroma atau bau dianggap penting karena cepat dapat memberikan hasil penilaian terhadap produk terkait diterima atau tidaknya suatu produk. Timbulnya aroma atau bau ini karena zat bau tersebut bersifat volatile (mudah menguap), sedikit larut air dan lemak. Kartika, dkk (1988) juga menambahkan bahwa aroma juga dapat dipakai sebagai suatu indikator terjadinya kerusakan pada produk, misalnya sebagai akibat dari pemanasan atau cara penyimpanan yang kurang baik ataupun adanya cacat (off flavor) pada suatu produk. Penanganan dan penyimpanan suatu produk makanan dapat menentukan aroma atau bau dari produk makanan yang mana aroma nerupakan salah satu faktor penentu kualitas produk makanan. Hasil pengujian organoleptik terhadap aroma asap bakso ikan tenggiri dengan penambahan asap cair dapat dilihat pada Tabel 2.

Tabel 2. Hasil Uji Organoleptik terhadap Aroma Asap Bakso Ikan Tenggiri dengan Penambahan Asap Cair

\begin{tabular}{llll}
\hline \multirow{2}{*}{ Perlakuan } & \multicolumn{3}{c}{ Skor Pembedaan Aroma } \\
& \multicolumn{3}{c}{ Asap } \\
\cline { 2 - 4 } & Asap & Asap & Asap \\
& Cair & Cair & Cair \\
& $3 \%$ & $5 \%$ & $7 \%$ \\
\hline Pencampuran & $3,55^{\mathrm{e}}$ & $3,20^{\mathrm{de}}$ & $2,90^{\mathrm{cd}}$ \\
Pencelupan & $1,85^{\mathrm{a}}$ & $2,40^{\mathrm{abc}}$ & $2,20^{\mathrm{ab}}$ \\
Penyemprotan & $2,55^{\mathrm{bc}}$ & $2,10^{\mathrm{ab}}$ & $2,00^{\mathrm{ab}}$ \\
\hline \hline
\end{tabular}

Ket: Angka dengan notasi yang sama berarti tidak beda nyata pada tingkat kepercayaan $95 \%$. Skala Nilai: 1) sangat kuat, 2) kuat, 3) agak kuat, 4) lemah, 5) sangat lemah

Tabel 2 menunjukkan bahwa interaksi antara metode dan konsentrasi penambahan asap cair memberikan pengaruh bervariasi terhadap aroma asap bakso ikan tenggiri. Bakso ikan tenggiri dengan metode pencelupan asap cair 3\% tidak berbeda nyata terhadap bakso ikan tenggiri dengan metode pencelupan asap cair (5\% dan 7\%) serta metode penyemprotan asap cair (5\% dan 7\%) tetapi berbeda nyata terhadap bakso ikan tenggiri dengan metode pencampuran asap cair $(3 \%, 5 \%$ dan $7 \%)$ serta metode penyemprotan asap cair 3\%.

Berdasarkan uji pembedaan yang ditinjau pada tiap perlakuan maka secara keseluruhan panelis sudah dapat membedakan aroma asap pada bakso ikan tenggiri dengan berbagai tingkat konsentrasi dalam tiap metode penambahan asap cair yang berbeda. Secara umum ditinjau dari tiap metode maka semakin besar penambahan konsentrasi asap cair maka aroma asap yang dihasilkan juga akan semakin kuat meskipun hasilnya tidak berbeda nyata. Penilaian ratarata yang diberikan oleh panelis terhadap aroma asap bakso ikan tenggiri dengan penambahan asap cair berada pada rentang nilai 2 (kuat). Hal ini berarti panelis menilai bahwa aroma asap pada bakso ikan yang dihasilkan cenderung kuat. 
Aroma asap yang dihasilkan pada bakso ikan tenggiri ini disebabkan adanya penambahan asap cair. Hal ini karena adanya kandungan senyawa fenol dalam asap cair. Menurut Girard (1992), senyawa fenol merupakan konstituen mayor yang berperan dalam pembentukan flavor pada produk asapan. Daun (1979) menambahkan bahwa karakteristik flavor pada produk asapan disebabkan oleh adanya komponen fenol yang terabsorbsi pada permukaan produk. Flavor/citarasa merupakan totalitas rasa dan aroma yang dirasakan selama mengkonsumsi makanan. Senyawa fenol yang berperan dalam pembentukan flavor asap adalah guaikol, 4-metil guaikol, dan 2,6-dimetoksi fenol. Senyawa fenol yang lebih berperan dalam pembentukan aroma asap adalah siringol.

\section{Rasa Asap}

Flavor atau rasa didefinisikan sebagi rangsangan yang ditimbulkan oleh bahan yang dimakan, yang dirasakan oleh indra pengecap atau pembau, serta rangsangan lainnya seperti perabaan dan penerimaan derajad panas oleh mulut. Flavor merupakan gabungan sifat-sifat khas bahan yang menghasilkan sensasi/rangsangan (De mann, 1989). Kartika, dkk (1988) juga menyatakan bahwa rasa dari suatu makanan merupakan gabungan dari berbagai macam rasa bahanbahan yang digunakan dalam makanan tersebut.

Rasa merupakan sensasi yang terbentuk dari hasil perpaduan bahan pembentuk dan komposisinya pada suatu produk makanan yang ditangkap oleh indra pengecap. Oleh sebab itu, rasa suatu produk makanan sangat dipengaruhi oleh komposisi bahan penyusun dalam makanan. Rasa merupakan atribut mutu dari suatu produk yang biasanya merupakan faktor penting bagi konsumen dalam memilih produk. Suatu produk dapat diterima oleh konsumen apabila memiliki rasa yang sesuai dengan yang diinginkan. Hasil pengujian organoleptik terhadap rasa asap bakso ikan tenggiri dengan penambahan asap cair dapat dilihat pada Tabel 3.
Tabel 3. Hasil Uji Organoleptik terhadap Rasa Asap Bakso Ikan Tenggiri dengan Penambahan Asap Cair

\begin{tabular}{llll}
\hline \hline \multirow{1}{*}{ Perlakuan } & \multicolumn{3}{c}{ Skor Pembedaan Rasa } \\
& \multicolumn{3}{c}{ Asap } \\
\cline { 2 - 4 } & Asap & Asap & Asap \\
& Cair & Cair & Cair \\
& $3 \%$ & $5 \%$ & $7 \%$ \\
\hline Pencampuran & $3,60^{\mathrm{d}}$ & $3,45^{\mathrm{cd}}$ & $3,00^{\mathrm{bc}}$ \\
Pencelupan & $2,55^{\mathrm{ab}}$ & $2,80^{\mathrm{ab}}$ & $2,35^{\mathrm{a}}$ \\
Penyemprotan & $3,00^{\mathrm{bc}}$ & $2,65^{\mathrm{ab}}$ & $2,65^{\mathrm{ab}}$ \\
\hline \hline
\end{tabular}

Ket: Angka dengan notasi yang sama berarti tidak beda nyata pada tingkat kepercayaan $95 \%$. Skala Nilai: 1) sangat kuat, 2) kuat, 3) agak kuat, 4) lemah, 5) sangat lemah

Tabel 3 menunjukkan bahwa interaksi antara metode dan konsentrasi penambahan asap cair memberikan pengaruh bervariasi terhadap aroma asap bakso ikan tenggiri. Bakso ikan tenggiri dengan metode pencelupan asap cair 7\% tidak berbeda nyata terhadap bakso ikan tenggiri dengan metode pencelupan asap cair (3\% dan 5\%) serta metode penyemprotan asap cair $(5 \%$ dan $7 \%)$ tetapi berbeda nyata terhadap bakso ikan tenggiri dengan metode pencampuran asap cair $(3 \%, 5 \%$ dan $7 \%)$ serta metode penyemprotan asap cair 3\%.

Berdasarkan uji pembedaan yang ditinjau pada tiap perlakuan maka seperti halnya aroma asap maka secara keseluruhan panelis juga sudah dapat membedakan rasa asap pada bakso ikan tenggiri dengan berbagai tingkat konsentrasi dalam tiap metode penambahan asap cair yang berbeda. Secara umum ditinjau dari tiap metode maka semakin besar penambahan konsentrasi asap cair maka rasa asap yang dihasilkan juga akan semakin kuat meskipun hasilnya tidak berbeda nyata. Penilaian rata-rata yang diberikan oleh panelis terhadap rasa asap bakso ikan tenggiri dengan penambahan asap cair berada pada rentang nilai 2 (kuat). Hal ini berarti panelis menilai bahwa rasa asap pada bakso ikan yang dihasilkan cenderung kuat.

Rasa asap yang dihasilkan pada bakso ikan tenggiri ini disebabkan adanya penambahan asap cair. Hal ini karena adanya kandungan senyawa fenol dalam asap cair. Menurut Girard (1992), senyawa fenol merupakan konstituen mayor yang berperan 
dalam pembentukan flavor pada produk asapan. Daun (1979) menambahkan bahwa karakteristik flavor pada produk asapan disebabkan oleh adanya komponen fenol yang terabsorbsi pada permukaan produk. Flavor/citarasa merupakan totalitas rasa dan aroma yang dirasakan selama mengkonsumsi makanan. Senyawa fenol yang berperan dalam pembentukan flavor asap adalah guaikol, 4-metil guaikol, dan 2,6-dimetoksi fenol. Senyawa fenol yang lebih berperan dalam pembentukan aroma asap adalah siringol.

\section{Kekenyalan}

Kekenyalan merupakan salah satu faktor penentu terhadap tingkat kesukaan konsumen. Sebagian besar konsumen lebih menyukai produk bakso terutama karena teksturnya yang kenyal, jika dikunyah terasa lembut dan rasanya enak (Anonim, 1993). Tekstur makanan dapat dievaluasi dengan uji mekanik (instrumen) atau dengan analisis secara pengindraan. Analisis secara pengindraan menggunakan alat indra manusia sebagai alat analisis (De mann, 1989). Hasil pengujian organoleptik terhadap kekenyalan bakso ikan tenggiri dengan penambahan asap cair dapat dilihat pada Tabel 4.

Tabel 4. Hasil Uji Organoleptik terhadap Kekenyalan Bakso Ikan Tenggiri dengan Penambahan Asap Cair

\begin{tabular}{llll}
\hline \hline \multirow{1}{*}{ Perlakuan } & \multicolumn{3}{c}{ Skor Pembedaan } \\
& \multicolumn{3}{c}{ Kekenyalan } \\
\cline { 2 - 4 } & Asap & Asap & Asap \\
& Cair & Cair & Cair \\
& $3 \%$ & $5 \%$ & $7 \%$ \\
\hline Pencampuran & $2,75^{\mathrm{b}}$ & $2,90^{\mathrm{b}}$ & $2,60^{\mathrm{ab}}$ \\
Pencelupan & $2,35^{\mathrm{ab}}$ & $2,45^{\mathrm{ab}}$ & $2,40^{\mathrm{ab}}$ \\
Penyemprotan & $2,15^{\mathrm{a}}$ & $2,60^{\mathrm{ab}}$ & $2,50^{\mathrm{a}}$ \\
\hline \hline
\end{tabular}

Ket: Angka dengan notasi yang sama berarti tidak beda nyata pada tingkat kepercayaan $95 \%$. Skala Nilai: 1) sangat kenyal, 2) kenyal, 3) agak kenyal, 4) kurang kenyal, 5) tidak kenyal

Tabel 4 menunjukkan bahwa interaksi antara metode dan konsentrasi penambahan asap cair tidak memberikan pengaruh beda nyata terhadap kekenyalan bakso ikan tenggiri kecuali pada bakso ikan tenggiri dengan metode pencampuran asap cair konsentrasi 3\% dan 5\%. Secara umum dapat disimpulkan bahwa penambahan asap cair tidak memberikan pengaruh terhadap kekenyalan bakso yang dihasilkan. Penilaian rata-rata yang diberikan oleh panelis terhadap kekenyalan bakso ikan tenggiri dengan penambahan asap cair berada pada rentang nilai 2 (kenyal). Hal ini berarti panelis menilai bahwa tekstur pada bakso ikan yang dihasilkan cenderung kenyal.

Ikan tenggiri selain warna dagingnya putih, juga memiliki kandungan aktin dan myosin cukup tinggi sehingga tekstur bakso yang dihasilkan bagus. Selain itu, menurut Haryadi (1993), penggunaan polifosfat sebagai bahan pengenyal yang digunakan bersama-sama dengan pati serta dilakukan pemanasan akan terjadi interaksi antara karbohidrat dan protein sehingga dihasilkan gel yang lebih kenyal. Menurut Sofos (1986), hal ini dapat terjadi karena senyawa polifosfat berfungsi untuk meningkatkan $\mathrm{pH}$ sehingga protein globular akan terekstrak yang nantinya berperan dalam pembentukan gel.

\section{Keseluruhan}

Kesukaan dan penerimaan konsumen terhadap suatu bahan mungkin tidak hanya dipengaruhi oleh satu faktor, akan tetapi dipengaruhi oleh berbagai macam faktor sehingga menimbulkan penerimaan yang utuh. Atribut keseluruhan ini hampir sama dengan kenampakan suatu produk secara keseluruhan, yang berfungsi untuk mengetahui tingkat penerimaan konsumen.

Hasil pengujian organoleptik terhadap atribut keseluruhan bakso ikan tenggiri dengan penambahan asap cair dapat dilihat pada Gambar 1.

Gambar 1 menunjukkan bahwa bakso antar perlakuan dengan variasi metode dan konsentrasi penambahan asap cair menghasilkan atribut keseluruhan bakso ikan tenggiri yang tidak berbeda nyata. Secara umum nilai yang diberikan oleh panelis terhadap atribut keseluruhan bakso ikan tenggiri dengan penambahan asap cair berkisar pada rentang nilai 2 (suka). Hal ini berarti panelis cenderung menyukai atribut keseluruhan bakso ikan tenggiri pada semua metode dan konsentrasi penambahan asap cair. Hal ini menunjukkan bahwa penambahan asap cair dapat digunakan 


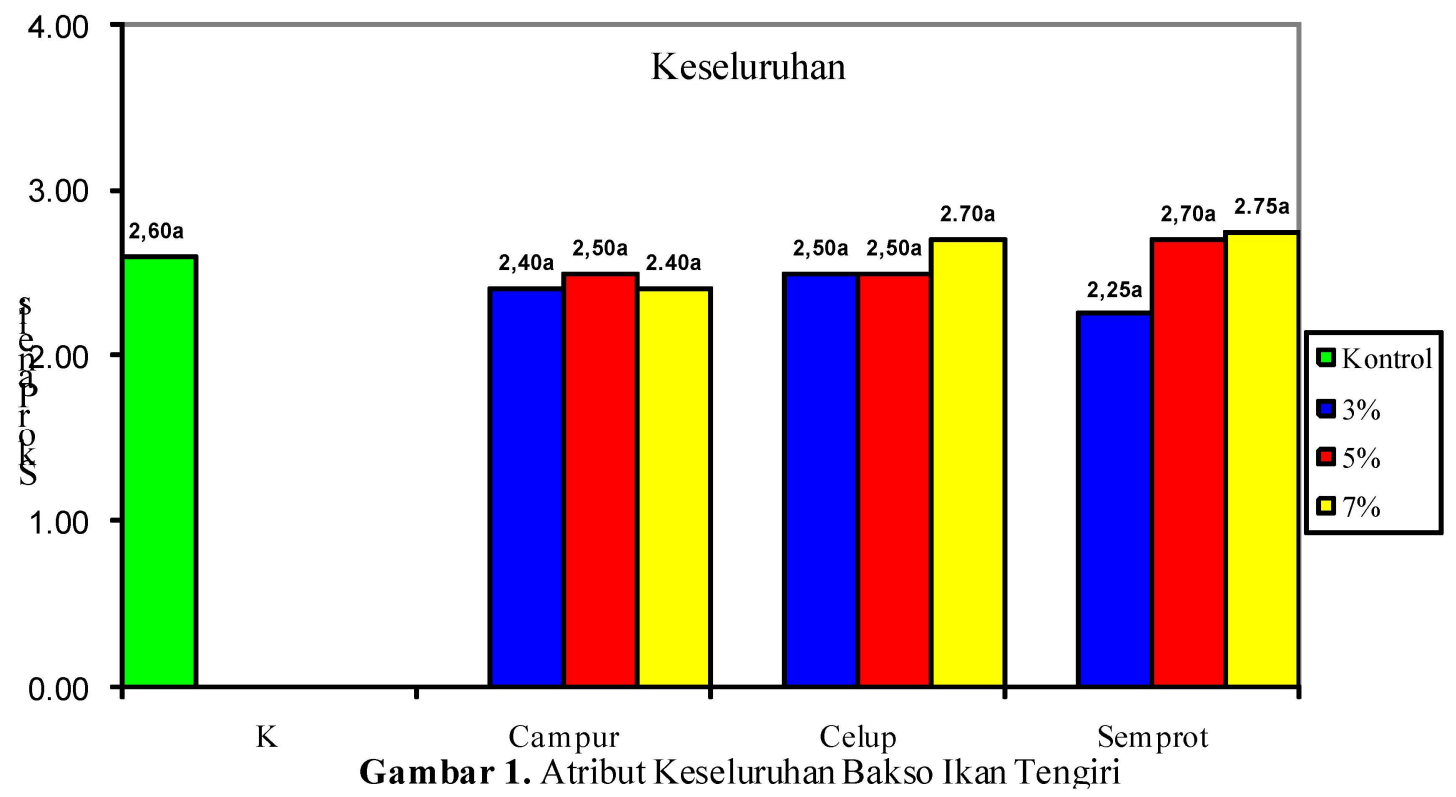

Ket: Angka dengan notasi yang sama berarti tidak beda nyata pada tingkat kepercayaan $95 \%$. Skala Nilai: 1) sangat suka, 2) suka, 3) agak suka, 4) tidak suka, 5) sangat tidak suka

sebagai alternatif dalam diversifikasi citarasa pada pembuatan bakso ikan tenggiri.

Berdasarkan hasil uji kesukaan secara keseluruhan dapat dilihat bahwa bakso ikan tenggiri dengan metode penyemprotan konsentrasi asap cair 3\% memiliki tingkat kesukaan paling tinggi dibandingkan bakso ikan tenggiri dengan metode dan konsentrasi asap cair yang lain meskipun tidak berbeda nyata. Bakso ikan tenggiri dengan metode penyemprotan konsentrasi asap cair 3\% memiliki tingkat kekenyalan yang paling tinggi meskipun tidak berbeda nyata dengan sampel lain serta memiliki aroma asap dan rasa asap yang tidak begitu kuat tapi juga tidak begitu lemah. Namun, ditinjau dari metode penambahan asap cair pada tiap metode secara umum dapat disimpulkan bahwa panelis cenderung menyukai bakso ikan tenggiri dengan aroma dan rasa asap pada konsentrasi rendah.

Bakso ikan tenggiri dengan metode penyemprotan konsentrasi asap cair 3\% juga memiliki tingkat kesukaan yang lebih tinggi dibandingkan bakso ikan tenggiri kontrol (tanpa penambahan asap cair). Oleh sebab itu, bakso ikan tenggiri dengan metode penyemprotan konsentrasi asap cair 3\% dalam penelitian ini selanjutnya dipilih untuk dilakukan uji fisik (tekstur) serta uji kimia (air, protein, lemak dan fenol).

\section{Karakteristik Fisik Bakso Ikan Tenggiri dengan Penambahan Asap Cair}

Pengukuran sifat fisik bakso ikan tenggiri ini dilakukan dengan menggunakan Llyod Instrument. Analisis tekstur dilakukan secara objektif karena memberikan hasil yang cepat, tepat, dan akurat (Purwiyatno, dkk 2007). Sifat fisik suatu produk sangat menentukan kualitas serta tingkat penerimaan konsumen terhadap produk tersebut. Untuk menguji sifat bakso ikan tenggiri secara obyektif dilakukan terhadap tingkat kekerasan dan kekenyalan. Hasil pengujian terhadap karakter fisik bakso ikan tenggiri dengan penyemprotan asap cair 3\% dapat dilihat pada Tabel 5.

Tabel 5. Hasil Uji Tekstur Llyod Instrument terhadap Kekerasan dan Kekenyalan Bakso Ikan Tenggiri dengan Penambahan Asap Cair

\begin{tabular}{|c|c|c|}
\hline \multirow[t]{2}{*}{ Perlakuan } & \multicolumn{2}{|c|}{$\begin{array}{l}\text { Skor Uji Fisik } \\
\text { Llyod }\end{array}$} \\
\hline & $\begin{array}{l}\text { F Max } \\
(\mathrm{N})\end{array}$ & $\begin{array}{l}\varepsilon \mathrm{F} \mathrm{Max} \\
(\mathrm{mm})\end{array}$ \\
\hline $\begin{array}{l}\text { Penyemprotan } \\
\text { Asap Cair 3\% }\end{array}$ & 63,78 & 18,31 \\
\hline
\end{tabular}

Kekerasan bakso dinyatakan dengan $\mathrm{F}$ Max sebesar 63,78 N sedangkan kekenyalan dinyatakan dengan $\varepsilon F$ Max 18,31 mm. Teknik pengujian kekerasan dilakukan 
dengan menentukan gaya maksimum yang diperlukan untuk memecah (shear force). Gaya maksimum (N) di sini ialah gaya maksimum yang diperlukan untuk memberi deformasi pada produk bakso hingga produk bakso tersebut mengalami kerusakan. Semakin tinggi gaya yang dibutuhkan untuk memecah dengan tingkat kerusakan yang sama, menunjukkan produk tersebut semakin keras. Produk yang mempunyai tingkat kekerasan tinggi maka apabila diberikan gaya maksimum sebesar $\mathrm{N}$ akan menimbulkan kerusakan yang tinggi pula pada produk tersebut.

Kekenyalan diukur berdasarkan kemampuan bahan melakukan deformasi elastis. Sifat kenyal ini dimiliki oleh gel termasuk bakso ikan. Menurut Anonim (1993), kekenyalan ditentukan oleh jenis daging, bahan, dan bumbu-bumbu yang ditambahkan, yang melibatkan interaksi patipati dan pati-protein. Teknik pengujian kekenyalan yang dinyatakan dengan gaya $\mathrm{F}$ Max (mm) dilakukan dengan menentukan selisih antara ketinggian bakso sebelum mengalami kerusakan atau hancur dengan ketinggian bakso pada saat mengalami kerusakan atau hancur setelah diberikan gaya $\mathrm{F} \operatorname{Max}(\mathrm{N})$.

Pada produk bakso terjadi gelasi polimer protein dari daging ikan dan karbohidrat yang berasal dari tepung tapioka yang disebabkan adanya pemanasan yang mengakibatkan tekstur bakso menjadi kenyal. Protein berperan dalam meningkatkan kekenyalan. Protein terdiri dari aktin dan myosin yang mempunyai kemampuan membentuk gel yang bagus (Rahardiyan, 2004).

\section{Karakteristik Kimia Bakso Ikan Tenggiri dengan Penambahan Asap Cair}

Dalam penelitian ini dilakukan analisis kimia bakso ikan tenggiri dengan metode penyemprotan konsentrasi asap cair $3 \%$ yang merupakan bakso dengan tingkat kesukaan paling tinggi pada pengujian organoleptik. Hasil Analisis kimia bakso ikan tenggiri dapat dilihat pada Tabel 6.
Tabel 6. Karakteristik Kimia Bakso Ikan Tenggiri dengan Penambahan Asap Cair

\begin{tabular}{lcc}
\hline \hline Parameter & $\begin{array}{c}\text { Penyem- } \\
\text { protan Asap } \\
\text { Cair 3\% }\end{array}$ & SNI \\
\cline { 2 - 3 } & wb (\%) & wb (\%) \\
\hline Kadar Air & $75,06 \%$ & Maks $80 \%$ \\
Kadar Protein & $10,16 \%$ & Min 9\% \\
Kadar Lemak & $0,86 \%$ & Maks 1\% \\
\hline \hline
\end{tabular}

Ket: kandungan berdasarkan berat basah (wb)

\section{Kadar Air}

Air merupakan komponen penting dalam bahan makanan. Kadar air sangat penting dalam menentukan daya awet dari bahan makanan karena mempengaruhi sifat fisik, kimia, perubahan mikrobiologi dan perubahan enzimatis. Air dalam bahan makanan dapat mempengaruhi daya tahan makanan dari serangan mikrobia (Winarno, 1991). Sehubungan dengan hal itu, maka kadar air suatu bahan cukup penting untuk diketahui. Kadar air merupakan salah satu parameter mutu bakso yang penting karena bakso merupakan produk makanan basah sehingga kadar air mempengaruhi umur simpannya.

Air juga merupakan salah satu komponen yang berperan besar dalam pembuatan bakso karena menentukan tekstur bakso. Naruki dan Kanoni (1992) menyatakan bahwa air yang ditambahkan pada pembuatan bakso berfungsi untuk memudahkan pencampuran dan menurunkan viskositas adonan. Auran dan Woods (1973) menambahkan bahwa penambahan air mengakibatkan adonan bakso menjadi lebih encer sehingga lebih mudah dicampur dengan komponen-komponen lain serta memudahkan dalam penghalusan.

Kadar air bakso ikan menurut SNI 013891-1995 yaitu maksimal 80\%. Jadi apabila dibandingkan dengan SNI yang ada, maka kadar air bakso ikan tenggiri dengan penambahan asap cair sebesar $75,06 \%$ telah memenuhi SNI yang ada.

\section{Kadar Protein}

Dalam keadaan asli di alam, protein merupakan senyawa bermolekul besar dan kompleks yang tersusun dari unsur-unsur $\mathrm{C}$, $\mathrm{H}, \mathrm{O}, \mathrm{N}, \mathrm{S}$ dan dalam keadaan kompleks ada 
unsur P. Protein dalam bahan biologis biasanya terdapat dalam bentuk ikatan fisis yang renggang maupun ikatan kimiawi yang lebih erat dengan karbohidrat ataupun lemak, karena ikatan-ikatan ini maka terbentuk senyawa-senyawa glikoprotein dan lipoprotein yang berperan besar dalam penentuan sifat-sifat fisis aliran bahan (rheologis), misalnya pada sistem emulsi makanan (Sudarmadji, dkk 1997).

Menurut Price dan Schweigert (1971), protein merupakan substansi pengikat air paling penting, dengan bertambahnya protein pada bakso maka ikatan protein-air akan kuat, sehingga lepasnya air dari jaringan dapat dicegah sehingga kadar air bakso dapat dipertahankan. Clark dan Tuffnell (1986) menambahkan bahwa protein merupakan salah satu komponen yang menentukan tekstur bakso karena kemampuannya membentuk gel.

Kadar protein bakso ikan menurut SNI 01-3891-1995 yaitu minimal 9\%. Jadi apabila dibandingkan dengan SNI yang ada, maka kadar protein bakso ikan tenggiri dengan penambahan asap cair sebesar $10,16 \%$ telah memenuhi SNI yang ada.

\section{Kadar Lemak}

Menurut Triyantini, dkk (1986), kadar lemak bakso tergantung dari macam daging yang digunakan. Price dan Schweigert (1971) juga menyatakan hal yang sama bahwa kadar lemak daging proses dipengaruhi oleh kadar lemak daging asalnya. Bertambahnya kadar air dan lemak di dalam produk olahan daging akan menambah keempukan produk. Selain itu, keberadan lemak tersebut berfungsi untuk membentuk produk yang kompak dan empuk, serta memperbaiki rasa dan aroma.

Kadar lemak bakso ikan menurut SNI 01-3891-1995 yaitu maksimal 1\%. Jadi apabila dibandingkan dengan SNI yang ada, maka kadar lemak bakso ikan tenggiri dengan penambahan asap cair sebesar $0,86 \%$ telah memenuhi SNI yang ada.

Analisis Fenol Asap Cair, Bakso Ikan Tenggiri Kontrol dan Bakso Ikan Tenggiri Citarasa Asap

Senyawa fenol sangat penting dalam produk asap, karena fenol berperan dalam menyumbangkan aroma dan rasa spesifik pada produk asapan (Girard, 1992). Tujuan dari analisis fenol ini adalah untuk mengetahui banyaknya fenol yang menempel pada produk untuk mempresentasikan banyaknya asap yang menempel pada bakso ikan tenggiri citarasa asap. Selain itu, dapat pula digunakan untuk mengetahui banyaknya fenol (asap cair) yang hilang selama proses penyemprotan. Analisis fenol dilakukan pada larutan asap cair dengan konsentrasi 3\%. Selain itu, juga dilakukan analisis fenol pada bakso ikan tenggiri kontrol serta bakso ikan tenggiri dengan metode penyemprotan asap cair 3\%. Kandungan senyawa fenol dapat dilihat pada Tabel 7.

Tabel 7. Kandungan Senyawa Fenol Asap Cair, Bakso Ikan Tenggiri dan Bakso Ikan Tenggiri dengan Penambahan Asap Cair

\begin{tabular}{lc}
\hline \hline \multicolumn{1}{c}{ Parameter } & $\begin{array}{c}\text { Kadar } \\
\text { Fenol }\end{array}$ \\
\cline { 2 - 2 } & $(\%)$ \\
\hline Asap Cair 3\% & $1,17597 \%$ \\
Bakso Ikan Tenggiri & $0,01722 \%$ \\
Bakso Ikan Tenggiri & $0,07061 \%$ \\
Citarasa Asap & \\
\hline \hline
\end{tabular}

Daun (1979) menyatakan bahwa karakteristik flavor pada produk asapan disebabkan oleh adanya komponen fenol yang terabsorbsi pada permukaan produk. Flavor/citarasa merupakan totalitas rasa dan aroma yang dirasakan selama mengkonsumsi bahan makanan. Senyawa fenol yang berperan dalam pembentukan flavor asap adalah guaikol, 4-metil guaikol, dan 2,6dimetoksi fenol. Guaikol lebih berperan dalam pembentukan rasa asap sedangkan siringol lebih berperan dalam pembentukan aroma asap.

Dari Tabel 7 diketahui bahwa kadar fenol pada bakso ikan tenggiri dengan penambahan asap cair lebih tinggi dibandingkan bakso ikan tenggiri kontrol (tanpa penambahan asap cair). Hal ini disebabkan oleh asap cair yang disemprotkan pada bakso ikan tenggiri sesaat setelah perebusan. Hal ini membuktikan bahwa proses penyemprotan segera setelah perebusan mampu menempelkan aroma dan citarasa asap pada bakso ikan tenggiri. 
Selain itu selama proses penyemprotan asap cair juga terjadi kehilangan kandungan senyawa fenol. Hal ini dapat dilihat dengan membandingkan kadar fenol dalam asap cair 3\% dengan kenaikan kadar fenol bakso ikan tenggiri citarasa asap dari kontrol. Diduga kehilangan kandungan senyawa fenol ini disebabkan karena adanya sebagian senyawa fenol berantai pendek yang memiliki titik didih lebih rendah, sehingga selama penyemprotan segera setelah perebusan, senyawa fenol rantai pendek sudah banyak yang menguap.

Menurut Davidson and Branen (1981) batas aman fenol dalam makanan adalah $0,02-0,1 \%$ atau $200-100 \mathrm{mg} / \mathrm{kg}$. Hasil analisis kadar fenol bakso ikan tenggiri dengan penyemprotan asap cair 3\% dengan rasio penyemprotan asap cair pada adonan 2:1 (b/v) adalah sebesar 0,07061\%. Bakso ikan tenggiri dengan penyemprotan asap cair 3\% yang mengandung fenol alami sebesar $0,07061 \%$ tersebut masih jauh dibawah batas maksimal kadar fenol yang diperbolehkan dalam bahan makanan sehingga aman untuk dikonsumsi dan dapat diterima konsumen dari karakter sensoris, fisik dan kimia.

\section{KESIMPULAN}

Metode penyemprotan asap cair dengan konsentrasi asap cair 3\% merupakan metode serta konsentrasi pemberian asap cair pada bakso ikan tenggiri yang mempunyai tingkat kesukaan paling tinggi. Variasi metode serta konsentrasi pemberian asap cair pada bakso ikan tenggiri tidak memberikan pengaruh beda nyata terhadap sifat sensori warna, kekenyalan serta keseluruhan akan tetapi memberikan pengaruh bervariasi terhadap sifat sensori aroma asap dan rasa asap. Karakteristik fisik kekerasan bakso dinyatakan dengan $\mathrm{F}$ Max sebesar 63,78 N sedangkan kekenyalan dinyatakan dengan $\varepsilon \mathrm{F}$ Max 18,31 mm. Karakteristik kimia bakso ikan tenggiri dengan penyemprotan asap cair $3 \%$ telah sesuai dengan persyaratan SNI bakso ikan yaitu: kadar air 75,06\%, kadar protein $10,16 \%$ dan kadar lemak $0,86 \%$. Bakso ikan tenggiri dengan penyemprotan asap cair 3\% mengandung fenol alami sebesar $0,07061 \%$ dan masih jauh dibawah batas maksimal kadar fenol yang diperbolehkan dalam bahan makanan sehingga aman untuk dikonsumsi serta dapat diterima konsumen dari karakter sensoris, fisik dan kimia.

\section{DAFTAR PUSTAKA}

Anonim. 2006. Potensi Perikanan Jawa Tengah. http// www.jawatengah.go.id. Diakses 2 Maret 2008.

2004. Tenggiri. Wikipedia Indonesia, ensiklopedia bebas berbahasa Indonesia. http://id.wikipedia.org/wiki/Tengiri (diakses 10 Oktober 2008)

1993. Bakso.

http://id.wikipedia.org/wiki/Bakso (diakses 10 Oktober 2008).

Aurand, L. W dan A. E. Wood. 1973. Food Chemistry. The Avi Pub Co. Inc., Westport. Connecticut.

Clarck, A.H., and C.D.L Tuffnell. 1986. Gelatin of Globular Proteins. In: Functional Properties of Food Macromolekuler, Mitchell, J.R., and D.a. Ledward. El Sevier Applied Science Publisher. London.

Daun, H., 1979. Interaction of Wood Smoke Component and Food. Food Tech. 35(5): 66-70.

Davidson, P. M and Branen, A. L. 1981. Antimicrobial Activity of Non Halogenated Phenolic Compound. Journal of Food Protect. 44 (8): 623632

De Mann, J. M. 1989. Principle of Food Chemistry. The Avi Pub Co. Inc., Westport. Connecticut.

Fennema, R. O. 1985. Food Chemistry $2^{\text {nd }}$ Edition. Revised and Expanded. Academic Press. New York.

Girard, J.P., 1992. Technology of Meat and Meat Product Smoking. Ellis Harwood. New York. London. Toronto. Sydney. Tokyu. Singapore. 162-201.

Gorbatov, V.M., N.N, Krylova, V.P. Volovinskaya, Y.N. Cyaskovkaya, K.I. Bazarova, R.I. Khlamova, and G.Y. Yakavlova, 1971. Liquid Smoke 
For Use in Cured Meat. Food Tech 25: $71-77$

Haryadi. 1993. Dasar-Dasar Pemanfaatan Ilmu Teknologi Pati. Agritech 13 (3):27.

Kartika, Bambang, Puji Hastuti dan Wahyu Supartono. 1988. Pedoman Uji Inderawi Bahan Pangan. UGM. Yogyakarta.

Maga. Y.A. 1987. Smoke in Food Processing. CRC Press. Inc. Boca Raton. Florida.: 1 - $3 ; 113$ - 138.

Price dan Schweigert. 1971. The Science of Meat an Meat Product. Willey Published. San Fransisco.

Purwiyatno Hariyadi, Sukarno, Abubakar Tawali. 2007. Food Service Management. Food Review 11(11).PT Media Pangan Indonesia. Bogor.

Pszczola, D.E., 1995. Tour Highlights Production and Users of Smoke Based Flavors. Food Tech (1)70-74.

Rahardiyan, Dino. 2004. Bakso (Traditional Indonesian Meatball) Properties with Postmortem Conditions and Cold Storage. Thesis. The Interdepartmental Program of Animal and Dairy Sciences Faculty of the Louisiana State University and Agricultural and Mechanical College.

Senter,S.D ; Robertson,JA ; and Meredith, F.I., 1989. Phenolic Compound of The Mesocarp of Cresthaven Peaches During Storage and Ripening. Juornal Food Science 54: 1259-1268

SNI. 1995. Bakso Ikan. Badan Standarisasi Nasional Indonesia.

Soekarto, S.T. 1990. Dasar-Dasar Pengawasan Mutu dan Standarisasi Mutu Pangan. IPB Press. Bogor.

Sofos. J.N., 1986. Use of Phosphates in Low Sodium Meat Product. Food Tech. 4(9): 52.

Sudarmadji, Slamet, Bambang Haryono dan Suhardi. 1997. Prosedur Analisa untuk Bahan Makanan dan Pertanian. Liberty. Yogyakarta.

Suwedo, hadiwiyoto, Purnomo Darmadji, Susana Rita Purwasari. 2000. Perbandingan Pengasapan Panas dan Penggunaan Asap Cair pada
Pengolahan Ikan: Tinjauan

Benzopiren, fenol dan Sifat Organoleptik Ikan Asap. Agritech 20 (I) 14-19

Triyantini, Sumarlin, Darma dan Sudarmono. 1986. Pengaruh Macam Giling dan Lama Pelayuan Terhadap Mutu Bakso Sapi. Prosiding Seminar Penelitian Pasca Panen Pertanian. Badan Litbang Pertanian. Departemen Pertanian.

Wibowo, Singgih. 1995. Industri Pengolahan Bakso Ikan dan Bakso Daging. Penebar Swadaya. Jakarta.

Winarno, F.G. 1991. Kimia Pangan dan Gizi. PT Gramedia. Jakarta. 